\title{
Erratum to: The role of thrombocytosis in prognostic evaluation of epithelial ovarian tumors
}

\author{
Tayfun Gungor $^{1} \cdot$ Mine Kanat-Pektas $^{1,2} \cdot$ Ayhan Sucak $^{1} \cdot$ Leyla Mollamahmutoglu $^{1}$
}

Published online: 18 August 2017

(C) Springer-Verlag GmbH Germany 2017

\section{Erratum to: Arch Gynecol Obstet (2009) 279:53-56}

\section{DOI 10.1007/s00404-008-0673-9}

The authors hereby declare that the original version of the article unintentionally included an illustration that is identical with one published in Li AJ, Madden AC, Cass I, Leuchter RS, Lagasse LD, Karlan BY. The prognostic significance of thrombocytosis in epithelial ovarian carcinoma. Gynecol Oncol 2004;92(1):211-4.

As the illustration was provided by a third party, the authors did not notice the double publication.

The raw data were re-evaluated and the results are presented in the new figure that has been provided together with this erratum.

The authors sincerely thank Dr. Alp Giray Ozen who reevaluated the original data for this illustration. As Dr. Alp Giray Ozen received a payment for his valuable efforts, he was not included as a co-author of this paper.

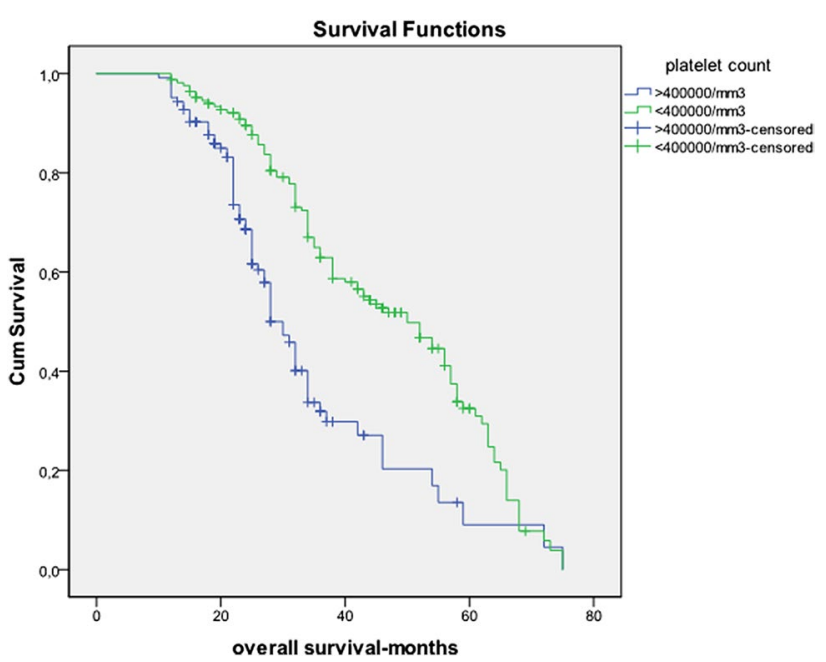

Fig. 1 Kaplan-Meier analysis of overall survival in dependence of thrombocytosis

The online version of the original article can be found under doi:10.1007/s00404-008-0673-9.

Mine Kanat-Pektas

minekanat@hotmail.com

1 Department of Gynecologic Oncology, Dr Zekai Tahir Burak

Women Health Education and Research Hospital, Ankara,

Turkey

2 Ertugrul Gazi Mah, Kutlugun Sok. No. 37/14,

06590 Iccebeci, Ankara, Turkey 